\title{
Influence of Plant Density and Cultivar on Mini Triploid Watermelon Yield and Fruit Quality
}

\author{
S. Alan Walters ${ }^{1,2}$
}

AdDitional INDEX words. Citrullus lanatus, in-row spacing, seedless, vegetable production

SUMMARY. Mini triploid (seedless) watermelons (Citrullus lanatus) are a growing segment of the U.S. watermelon market due to their small, one-serving size. Although mini triploid watermelons were first released and commercially grown about 6 years ago, little information is available for optimum planting densities that are needed to achieve the greatest percentage of marketable fruit in the 3- to 8-1b range. In 2006 and 2007, the fruit grade distribution response to six plant densities $(2489,3111,4149,6223,8297$, and 12,446 plants/acre) of four mini watermelon cultivars (Betsy, Petite Treat, Valdoria, and Vanessa) was measured at the Southern Illinois University Horticulture Research Center in Carbondale. 'SP-1' was used as the in-row pollenizer at $25 \%$ of the total planting. Although all cultivars responded similarly to the plant densities evaluated, 'Vanessa' provided the greatest fruit number and weight per acre, and percentage of fruit in the mini grade, compared with the other cultivars. Marketable mini triploid watermelon yield dramatically increased with closer in-row spacings. At lower plant densities (wider in-row spacings), a greater proportion of icebox-sized fruit ( $>8 \mathrm{lb}$ ) was produced, and the amount of marketable, mini-sized fruit (3-8 lb) declined. The grade distribution of mini triploid watermelon numbers and weights were the greatest at the highest plant density evaluated $[0.5 \mathrm{ft}$ in-row spacing $(12,446$ plants/acre $)]$, with about $80 \%$ of the total yield in the mini grade. The greatest net revenues were also obtained at this high density. This study indicated that it is critical for producers of mini triploid watermelons to recognize the dramatic impact that plant density has on marketable fruit yield (3-8 lb). Growers of mini triploid watermelons will see a drastic improvement in revenues with closer in-row spacings compared with the approximate $2 \mathrm{ft}$ in-row spacings currently used (about 4000 plants/acre). The increased cost of higher plant densities are more than offset by the greater return on investment.

A lthough mini triploid watermelons are a relatively new specialty vegetable, they have captured a segment of the watermelon market due to their convenience (Maynard and Perkins-Veazie, 2004). These types of watermelons garner a premium retail price ranging from $\$ 4$ to $\$ 5$ for a marketable 3- to 8 -lb fruit (Schultheis et al., 2007). Desirable traits for mini triploid watermelons include oval- or round-shaped fruit in the 3 - to 8 -lb range, and an attractive solid or striped fruit rind that is also thin and tough. The flesh should be dark red, crisp, sweet, and seedless (Maynard and Perkins-Veazie, 2004).

Although extensive work has been done to identify high-yielding mini triploid watermelon cultivars (Maynard and Perkins-Veazie, 2004; Schultheis et al., 2007; Strang et al., 2004), little has been done to determine the optimum spacing for mini triploid watermelon to obtain the highest percentages of marketable fruit (packout) in the 3 - to 8 -lb range. Increasing watermelon plant densities by using closer in-row plant spacings have generally resulted in reducing the fruit size of large and small seeded watermelon cultivars (Duthie et al., 1999b; NeSmith, 1993; Sanders et al., 1999). Preliminary reports suggest that the production of marketable mini triploid watermelons seems to increase with closer plant spacings (Thompson and Schultheis, 2008; Strang et al., 2005). Most commercial seed suppliers recommend using about half the standard in-row spacings (about $2 \mathrm{ft}$ or $\approx 4000$ plants/acre) that are used for largesized watermelons to maximize mini triploid watermelon yields. Therefore, due to the limited information available from multiyear, replicated studies regarding mini triploid watermelon planting densities, a study was conducted to determine the plant densities needed to obtain the highest percentage of marketable (3-8 lb) mini triploid watermelon fruit.

\section{Materials and methods}

The experiment was conducted at the Southern Illinois University Horticulture Research Center in Carbondale during 2006 and 2007. The experiment was designed as a splitplot with three replications. The main plot treatments were six in-row plant spacings: 1) $0.5 \mathrm{ft}(12,446$ plants/ acre $), 2) 0.75 \mathrm{ft}$ ( 8297 plants/acre), 3) $1 \mathrm{ft}$ (6223 plants/acre), 4) $1.5 \mathrm{ft}$ (4149 plants/acre), 5) $2 \mathrm{ft}(3111$ plants/acre), and 6) $2.5 \mathrm{ft}(2489$ plants/acre). Subplots consisted of four mini triploid watermelon cultivars: Betsy, Valdoria, and Vanessa from Nunhems USA (Parma, ID); and Petitie Treat from Zeraim Gedera Seed (Palm Desert, CA). Plots were $10 \mathrm{ft}$ in length. 'SP-1' pollenizer
I gratefully acknowledge the technical assistance of Doug Bogard (research horticulturalist) and several former graduate students, including Nathan Johanning, Robert Britenstine, Frank Dorris, and Jamie Stieg. I also thank Dr. Bradley $\mathrm{H}$. Taylor for providing a thorough review and suggestions for improvement of the manuscript.

The use of trade names in this publication does not imply endorsement of the products named or criticism of similar ones not mentioned.

${ }^{1}$ Associate Professor, Department of Plant, Soil, and Agricultural Systems, Southern Illinois University, Carbondale, IL 62901

${ }^{2}$ Corresponding author. E-mail: awalters@siu.edu.

\begin{tabular}{llll}
\hline $\begin{array}{l}\text { Units } \\
\text { To convert U.S. to SI, } \\
\text { multiply by }\end{array}$ & U.S. unit & SI unit & $\begin{array}{l}\text { To convert SI to U.S., } \\
\text { multiply by }\end{array}$ \\
\hline 0.4047 & $\mathrm{acre}(\mathrm{s})$ & $\mathrm{ha}$ & 2.4711 \\
0.3048 & $\mathrm{ft}$ & $\mathrm{m}$ & 3.2808 \\
0.1242 & $\mathrm{gal} / 100 \mathrm{ft}$ & $\mathrm{L} \cdot \mathrm{m}^{-1}$ & 8.0520 \\
2.54 & inch $(\mathrm{es})$ & $\mathrm{cm}$ & 0.3937 \\
0.4536 & $\mathrm{lb}$ & $\mathrm{kg}$ & 2.2046 \\
1.1209 & $\mathrm{lb} / \mathrm{acre}$ & $\mathrm{kg} \cdot \mathrm{ha}^{-1}$ & 0.8922 \\
0.0254 & $\mathrm{mil}$ & $\mathrm{mm}$ & 39.3701 \\
2.3385 & $\mathrm{qt} / \mathrm{acre}$ & $\mathrm{L} \cdot \mathrm{ha}^{-1}$ & 0.4276 \\
0.9072 & ton $(\mathrm{s})$ & $\mathrm{Mg}$ & 1.1023
\end{tabular}

Hortlechnology · July-September 2009 19(3) 
plants (Syngenta, Research Triangle Park, NC) were also planted every fourth plant in the row among the mini triploid watermelon plants. Although the number of pollenizer plants varied per 120 -ft-long row from 12 to 60, a triploid to pollenizer ratio of $3: 1$ or $4: 1$ was always maintained in each plot, which should have provided sufficient amounts of pollen for triploid fruit set (Fiacchino and Walters, 2003).

Watermelon seeds were planted in early May into 72-cell plastic trays (TLC Polyform, Plymouth, MN) containing a soilless media consisting of peatmoss (Conrad Fafard, Agawam, MA), vermiculite (Sun Gro Horticulture, Pine Bluff, AR), and perlite (Lite Weight Products, KS City, KS) in a 2:1:1 ratio by volume. Seedlings remained in the greenhouse for 2 weeks after emergence until plants had reached the one- to two- true-leaf stage. Transplants were then hardened-off in coldframes for 1 week before transplanting. Watermelon plants were transplanted into 6-inchhigh raised beds that were formed on 7 - $\mathrm{ft}$ centers and covered with 6 -ftwide, 1.25-mil black plastic mulch. The field soil was a Hosmer silt loam (fine-silty, mixed, mesic Typic Fragiudalfs) (Herman, 1979). Before bed formation, $40 \mathrm{lb} /$ acre nitrogen $(\mathrm{N})$ from ammonium nitrate $\left(\mathrm{NH}_{4} \mathrm{NO}_{3}\right)$, $52 \mathrm{lb} /$ acre phosphorus pentoxide $\left(\mathrm{P}_{2} \mathrm{O}_{5}\right)$, and $98 \mathrm{lb} /$ acre potassium oxide $\left(\mathrm{K}_{2} \mathrm{O}\right)$ from potassium chloride $(\mathrm{KCl})$ were broadcast and incorporated. Beginning at the four- to fivetrue-leaf stage, 3 to $5 \mathrm{lb} /$ acre $\mathrm{N}$ from calcium nitrate $\left[\mathrm{Ca}\left(\mathrm{NO}_{3}\right)_{2}\right]$ was applied weekly through the drip fertigation system $(0.22 \mathrm{gal} / 100 \mathrm{ft}$ per minute) as recommended by Sanders et al. (1995). Diseases and insects were controlled with standard foliar sprays of esfenvalerate (Asana; E.I. du Pont de Nemours, Wilmington, DE) and chlorothanil (Bravo; Zeneca, Wilmington, DE) at 10-d intervals starting at the four- to five true-leaf stage (Egel et al., 2006). Applications of paraquat dichloride (Gramoxone Max; Syngenta Crop Protection, Greensboro, NC) at $1 \mathrm{qt} / \mathrm{acre}$, as well as mechanical cultivation, were used to suppress weed growth between rows of plastic. When plants were in full flower, a honeybee colony $(>25,000$ bees) was placed within $50 \mathrm{~m}$ of the test site each year.
Mature watermelon fruit from each plot were harvested, weighed, and recorded twice during a 2-week period beginning in early August. Watermelons were harvested based on the presence of a desiccated tendril opposite the fruit pedicle and yellow coloration of the fruit belly (portion touching the ground). Four watermelons per plot were examined at the first harvest for hollow heart damage, soluble solids, rind thickness (in inches), and number of colored seed that were readily visible within the flesh on both halves of a longitudinally cut fruit. For hollow heart, the width of the gap in the flesh at its widest point was determined in inches. Soluble solids were also tested on the same watermelons using a hand-held refractometer (Fisher Scientific, Pittsburgh) measuring one sample from the central portion of the cut flesh at $0 \%$ to $18 \%$. Fruit rind thickness was measured as the width of the white rind extending from the skin surface to the red flesh.

Watermelons were separated into three grade classifications before analysis: micro $(<3 \mathrm{lb})$, mini $(3-8 \mathrm{lb})$ and icebox $(>8-13 \mathrm{lb})$. Analysis of variance procedures were performed using the general linear models procedure of SAS (version 8.2; SAS Institute, Cary, NC) to identify the seedless watermelon cultivars having the highest yields in the mini class, as well as superior horticultural quality characteristics. Regression analysis was also used to determine the relationship between plant density and yield for each grade (fruit numbers and weights per acre, as well as fruit numbers per plant). The impact of plant density on calculated gross and net revenues were also determined. Watermelon transplants are normally sold in bundles that contain 1000 mini triploid and 250 pollenizer plants for $\approx \$ 415$, which directly relates to a $4: 1$ seedless to pollenizer ratio (C. Mathis, personal communication); other fixed and variable costs (not including labor) are about $\$ 4000$ for watermelons produced on black plastic mulch and were based on watermelon production budgets from California (Meister, 2004) and Florida (Smith and Taylor, 2007). Although harvest costs will vary substantially depending on watermelon size, amount of resorting, container packed, transportation, and other miscellaneous fees, labor costs were estimated at $\$ 0.0375 / \mathrm{lb}$ for the harvested fruit weight for a particular density. This estimate was based on paying laborers $\$ 7.50 / \mathrm{h}$, which related to about $\$ 75 /$ ton of harvested fruit based on the watermelon production budget for California (Meister, 2004). Locally grown mini seedless watermelon typically sell for about $\$ 3.50$ each in farm markets, while the grower that uses wholesale markets will garner about $\$ 1.40$ for each watermelon (J. Schultheis, personal communication). In many wholesale markets, the micro-sized fruit are considered culls and have no value. Partial budget analysis can be useful to determine if changes in watermelon management practices increase revenues and require three types of information including yield, market price, and production costs (Lu et al., 2003). Therefore, partial budget analysis was used to determine the effect of mini triploid watermelon plant density on revenues obtained in local and wholesale markets for mini-sized fruit.

\section{Results}

The analysis indicated no interactions $(P>0.05)$ between years and mini triploid watermelon cultivar or

Table 1. Mini triploid watermelon cultivar quality characteristics combined over the 2006 and 2007 growing seasons.

\begin{tabular}{lcccc}
\hline Cultivar & $\begin{array}{c}\text { Hollow } \\
\text { heart (inch) }\end{array}$ & $\begin{array}{c}\text { Colored } \\
\text { seed (no.) }\end{array}$ & $\begin{array}{c}\text { Fruit rind } \\
\text { thickness (inch) }\end{array}$ & $\begin{array}{c}\text { Soluble } \\
\text { solids (\%) }\end{array}$ \\
\hline Betsy & $0.2 \mathrm{~b}^{\mathrm{v}}$ & $1.4 \mathrm{ab}$ & $1.0 \mathrm{a}$ & $11.8 \mathrm{~b}$ \\
Petite Treat & $4.1 \mathrm{a}$ & $0.7 \mathrm{~b}$ & $0.5 \mathrm{a}$ & $12.6 \mathrm{a}$ \\
Valdoria & $0.3 \mathrm{~b}$ & $2.4 \mathrm{a}$ & $0.5 \mathrm{a}$ & $11.8 \mathrm{~b}$ \\
Vanessa & $0.7 \mathrm{~b}$ & $0.6 \mathrm{~b}$ & $0.8 \mathrm{a}$ & $11.6 \mathrm{~b}$ \\
\hline
\end{tabular}

${ }^{\mathrm{z}}$ Hollow heart was measured as the width of the gap in the separated flesh at its widest point; 1 inch $=2.54 \mathrm{~cm}$. ${ }^{y}$ Number of colored seed readily visible on or near the flesh surface of a longitudinally cut fruit. ${ }^{x}$ Fruit rind thickness was the width of the white rind extending from the red flesh to the skin surface. wSoluble solids were measured using a hand-held refractometer measuring from $0 \%$ to $18 \%$.

${ }^{\vee}$ Means followed by the same letter within a column do not differ significantly according to Fisher's protected least significant difference at $P \leq 0.05$. Fruit harvested about $80 \mathrm{~d}$ after transplanting. 
plant density for all dependent variables evaluated, therefore years were combined. Furthermore, no interactions $(P>0.05)$ were detected between cultivar and plant density for all variables evaluated, indicating that all cultivars responded similarly to the plant densities evaluated.

MINI TRIPLOID WATERMELON QUALITY CHARACTERISTICS. Watermelon fruit quality was not influenced by plant density (data not presented), but was frequently affected by cultivar (Table 1). 'Petite Treat' had low amounts of colored seed in the edible flesh and high soluble solids, but had the highest amounts of hollow heart compared with the other cultivars. 'Betsy', 'Valdoria', and 'Vanessa' had negligible hollow heart injury, with soluble solids not differing among these three cultivars. 'Vanessa' had low numbers of colored seed, similar to 'Petite Treat'. All four cultivars had similar fruit rind thickness, ranging from 0.8 to 1.0 inches.

Mini SEedLess WATERMELON CULTIVAR YIELDS. 'Vanessa' produced the greatest number $(80 \%$ of total $)$ and weight $(81 \%$ of total) of fruit in the mini class (Table 2). 'Petite Treat' yielded the lowest total fruit number, weight per acre, and melon number per plant compared with the other cultivars. Furthermore, 'Petite Treat' and 'Valdoria' had the lowest percentages of mini-sized fruit numbers at $66 \%$ and $71 \%$, respectively, as well as the lowest percentage of mini-sized fruit weights at $59 \%$ and $66 \%$, respectively. 'Valdoria' produced large numbers of icebox-grade fruit that were greater than 'Betsy', 'Petite Treat', or 'Vanessa'.

SPACING EFFECTS ON MINI SEEDLESS WATERMELON YIELD. As inrow spacings were reduced from 2.5 to $0.5 \mathrm{ft}$, micro fruit number increased in a linear manner, and mini and total fruit number increased quadratically (Table 2); furthermore, icebox fruit number per acre decreased in a quadratic manner (from 2963 to 1245). The $0.5 \mathrm{ft}$ in-row spacing provided the greatest micro, mini, and total fruit number per acre. Reducing the in-row spacing provided an increase in microand mini-grade fruit weight, as well as total fruit weight in the same trend response as fruit number had exhibited, while icebox fruit weight decreased.

The relationship of total fruit numbers produced per plant with

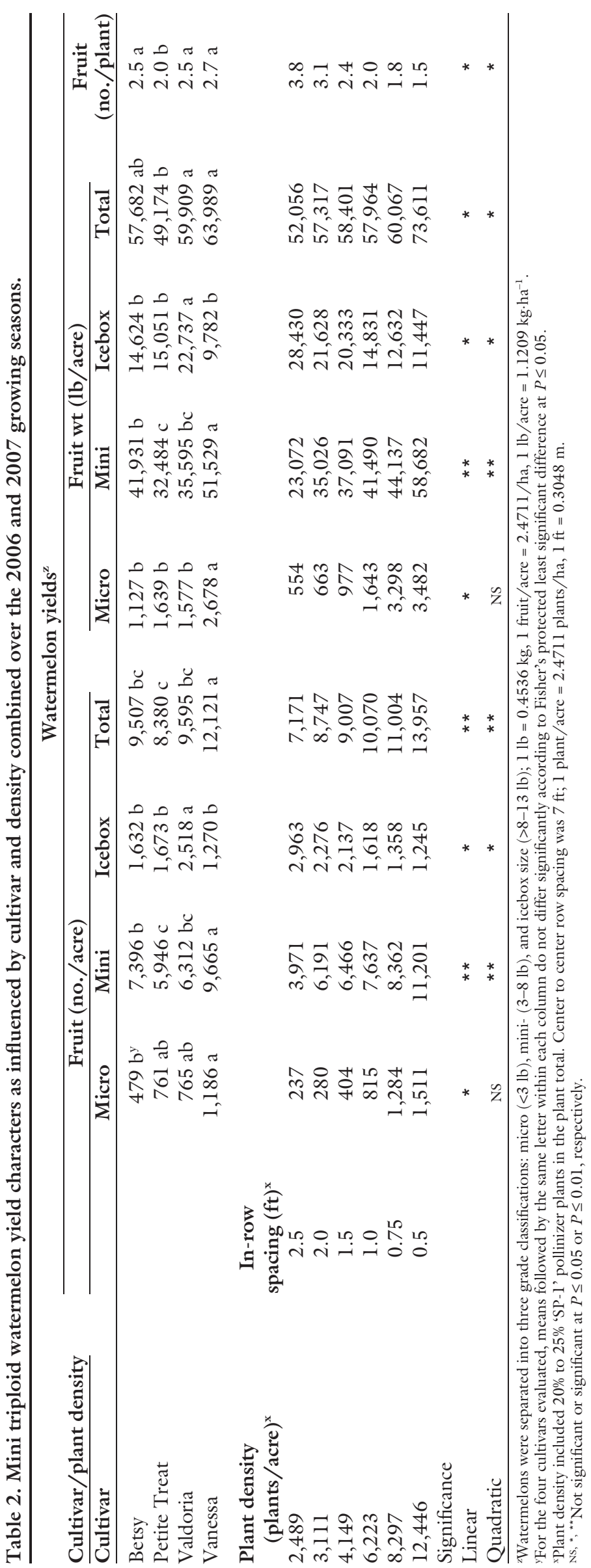




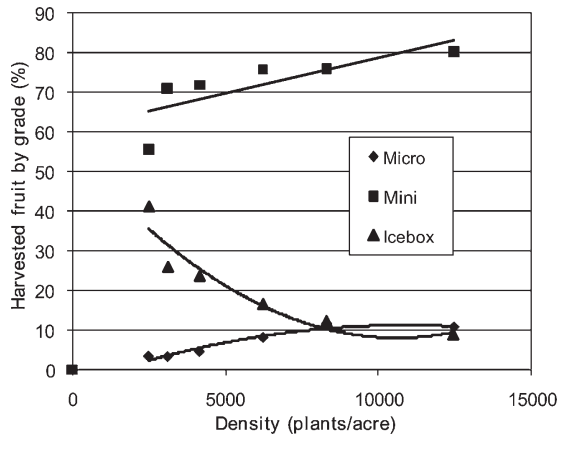

Fig. 1. The effect of mini triploid watermelon plant density on the percentage of micro-, mini-, and icebox-sized watermelon fruit numbers produced. The grade distribution by fruit size class (\%) was based on total fruit numbers produced per acre. Watermelons grade classes were: micro $(<3 \mathrm{lb})$, mini $(3-8 \mathrm{lb})$, and icebox $(>8-13 \mathrm{lb})(1 \mathrm{lb}=0.4536 \mathrm{~kg})$. Curves presented represent best-fit regressions with plant density. For percentage of micro and icebox fruit numbers produced per acre, quadratic models best explained the relationship with inrow plant density: $y$ ( $\%$ microsize fruit numbers) $=-3.964+0.003$ (plant density) $-1.300 \times 10^{-7}$ (plant density $)^{2}, \mathrm{R}^{2}=0.95, P=0.0127 ; \mathrm{y}(\%$ icebox-size fruit numbers $)=\mathbf{5 5 . 4 5 0 -}$ 0.009 (plant density) $+4.282 \times 10^{-7}$ (plant density) $)^{2}, \mathrm{R}^{2}=0.90, P=0.0328$. For mini fruit numbers produced per acre, a linear model best explained the relationship with in-row plant density: $\mathrm{y}(\%$ mini-size fruit numbers $)=60.817+$ 0.002 (plant density), $\mathrm{R}^{2}=0.60, P=$ 0.0725 . Plant density included $25 \%$ 'SP-1' pollinizer plants in the plant total; 1 plant $/$ acre $=2.4711$ plants $/$ ha.

in-row spacings were best described by a quadratic model (Table 2 ). As inrow spacings increased from 0.5 to $2.5 \mathrm{ft}$, the number of fruits produced per plant also increased. Although only 1.5 fruit per plant were produced on average at the $0.5 \mathrm{ft}$ spacing, a 5 fold increase in plant density almost doubled the total number of fruit from 7,171 to 13,957 per acre.

A quadratic relationship best described the slight increase of micro-sized fruit numbers produced per acre from $3.3 \%$ to $10.8 \%$ as plant density increased from 2,489 to 12,446 plants/acre (Fig. 1). The greatest percentage of mini-sized fruit numbers occurred at the closest in-row spacing, as about $80 \%$ were produced at the 12,446 plants/acre density. The percentage of iceboxsize fruit decreased with density as

Table 3. The effect of mini triploid watermelon plant density on partial budget analysis using marketable yields combined over the 2006 and 2007 growing seasons.

\begin{tabular}{|c|c|c|c|c|c|c|c|c|}
\hline \multirow{2}{*}{$\begin{array}{l}\text { Plant } \\
\text { density } \\
\text { (plants } / \text { acre })^{2}\end{array}$} & \multirow{2}{*}{$\begin{array}{c}\text { In-row } \\
\text { spacing } \\
(\mathrm{ft})^{\mathrm{z}}\end{array}$} & \multicolumn{3}{|c|}{$\begin{array}{c}\text { Costs } \\
(\$ / \text { acre })^{\mathrm{z}}\end{array}$} & \multicolumn{2}{|c|}{$\begin{array}{c}\text { Gross } \\
\text { revenues } \\
(\$ / \text { acre })^{v}\end{array}$} & \multicolumn{2}{|c|}{$\begin{array}{c}\text { Net } \\
\text { revenues } \\
(\$ / \text { acre })^{u}\end{array}$} \\
\hline & & $\begin{array}{l}\text { Plant } \\
\cos ^{\mathrm{y}} \mathrm{s}^{\mathrm{y}}\end{array}$ & Labor $^{\mathrm{x}}$ & Total $^{\mathrm{w}}$ & Local & Wholesale & Local & Wholesale \\
\hline 2,489 & 2.5 & 826 & 1,952 & 6,778 & 13,899 & 5,559 & 7,121 & $-1,219$ \\
\hline 3,111 & 2.0 & 1,033 & 2,149 & 7,182 & 21,669 & 8,667 & 14,487 & 1,485 \\
\hline 4,149 & 1.5 & 1,378 & 2,190 & 7,568 & 22,631 & 9,052 & 15,063 & 1,484 \\
\hline 6,223 & 1.0 & 2,066 & 2,174 & 8,240 & 26,730 & 10,692 & 18,490 & 2,452 \\
\hline 8,297 & 0.75 & 2,755 & 2,253 & 9,008 & 29,267 & 11,707 & 20,259 & 2,699 \\
\hline 12,446 & 0.5 & 4,132 & 2,760 & 10,892 & 39,201 & 15,681 & 28,309 & 4,789 \\
\hline \multicolumn{9}{|l|}{ Significance } \\
\hline Linear & - & - & * & * & ** & ** & ** & ** \\
\hline Quadratic & - & - & ** & ** & ** & ** & * & NS \\
\hline
\end{tabular}

${ }^{\mathrm{z}} \mathrm{l}$ plant $/$ acre $=2.471 \mathrm{l}$ plants $/ \mathrm{ha}, \mathrm{l} \mathrm{ft}=0.3048 \mathrm{~m}, \$ 1 /$ acre $=\$ 2.471 \mathrm{l} / \mathrm{ha}$.

${ }^{y}$ Mini seedless watermelon plants for field planting costs figured at $\$ 415$ per 1250 -plant bundles [ 1000 seedless and 250 pollenizer plants (4:1 seedless to pollenizer ratio) (C. Mathis, personal communication)].

${ }^{x}$ Labor costs were also estimated at $\$ 0.0375 / \mathrm{lb}(\$ 0.08267 / \mathrm{kg})$ for all harvested fruit weight for a particular density. This estimate was based on paying laborers $\$ 7.50 / \mathrm{h}$, which related to about $\$ 75 / \mathrm{ton}(\$ 82.67 / \mathrm{Mg})$ of harvested fruit based on the watermelon production budget for California (Meister, 2004).

wTotal costs were estimated from an approximate $\$ 4000$ fixed and variable costs (without labor) based on black plastic mulch watermelon production budgets in California (Meister, 2004) and Florida (Smith and Taylor, 2007) + plant costs + labor costs.

${ }^{\vee}$ Gross revenues were calculated from mini-sized triploid watermelon fruit number obtained per acre multiplied by $\$ 3.50$ and $\$ 1.40$ per piece for local and wholesale markets, respectively, for each plant density evaluated. Locally grown mini triploid watermelon typically sell for about $\$ 3.50$ each in farm markets, while the grower that uses wholesale markets will garner about $\$ 1.40$ for each watermelon (J. Schultheis, personal communication).

uNet revenues were calculated based on: gross revenues - total costs.

NS, *, ** Not significant or significant at $P \leq 0.05$ or $P \leq 0.01$, respectively.

less than $10 \%$ were found in this grade at the highest plant density (12,446 plants/acre). Results for the percentages of micro-, mini-, and icebox-sized fruit weight per acre were similar to that obtained for fruit number (data not shown).

Potential Revenue generATION BY PLANT DENSITY. Increased plant densities improved gross and net revenues from mini-sized triploid watermelon fruit. Although watermelon transplant and labor costs were the greatest at the 12,446 plants /acre density, the highest net revenues per acre occurred at this density with $\$ 28,309$ and $\$ 4,789$ for local and wholesale markets, respectively (Table 3 ). The net revenue generally dropped at each level of plant density as it declined from 8297 to 3111 plants/acre. At the 2489 plants/acre density, net revenues were \$7121 and -\$1219 for local and wholesale markets, respectively.

\section{Discussion}

It is critical that producers of mini triploid watermelons recognize the dramatic impact that plant density has on marketable fruit yields (3-8 lb). Our study indicated that the grade distribution of mini triploid watermelon numbers and weights were the greatest at the highest plant density evaluated $[0.5 \mathrm{ft}$ in-row spacing $(12,446$ plants/acre $)]$ with about $80 \%$ of the total yields in the mini-grade at this density. Using large triploid watermelon cultivars, Motsenbocker and Arancibia (2002) suggested that growers should be able to adjust in-row spacings to achieve a particular range in triploid watermelon fruit size; and, small-sized fruit (8-14 lb) provided the largest fruit category providing $54 \%$ of the total yield at the closest in-row spacing evaluated $(2 \mathrm{ft})$. Furthermore, from a 1-year preliminary study, Strang et al. (2005) indicated that higher plant densities (7260 and 4840 plants/acre) provided the greatest marketable numbers of mini 'Mohican' triploid watermelons compared with lower densities (3630 and 2904 plants/acre), and similar to our results, wider in-row spacings (lower plant densities) resulted in high numbers of icebox-size (>8-13 lb) triploid watermelon fruit.

Several studies, including Duthie et al. (1999b), Motsenbocker and Arancibia (2002), and Sanders et al. (1999) indicated that closer in-row watermelon plant spacings result in lower fruit numbers per plant 
compared with wider spacings, and this affect was also observed on the mini triploid watermelon cultivars evaluated (Table 2). Furthermore, Duthie et al. (1999a) indicated that watermelon yield per plant tends to decrease with higher plant densities because interplant competition intensifies and this directly suppresses plant growth, resulting in lower yields per plant.

Although Duthie et al. (1999a) states that the potential yield of watermelon genotypes varies with plant density (especially average fruit size at harvest), the four mini triploid watermelon cultivars evaluated herein responded similarly to plant density. However, 'Vanessa' clearly provided the greatest yields and a high percentage of mini-sized fruit compared with the other cultivars evaluated, which was similar to results from Maynard and Perkins-Veazie (2004) and Strang et al. (2005).

Although Strang et al. (2005) suggested that high plant populations (7260 and 4840 plants/acre) provided the greatest marketable numbers of mini 'Mohican' triploid watermelon, our results indicated that even higher plant densities $(8,297$ and 12,446 plants/acre) can be used to increase marketable triploid mini watermelon number and weight. However, growers should also consider the increase in seed or plant costs that are needed for these high plant populations. Seedless watermelon plant costs for field planting are five times greater when using $0.5 \mathrm{ft}$ in-row spacing compared with $2.5 \mathrm{ft}$ (Table 3). However, our study indicated that the greatest net revenues were obtained at the highest density evaluated $(0.5 \mathrm{ft}$ in-row spacing or 12,446 plants/acre). Growers should see a drastic improvement in revenues with closer in-row plant spacings (Table 3 ). Based on our results, growers can reduce their inrow spacing to $0.5 \mathrm{ft}$ with a concomitant increase in net revenue. This would increase the mini triploid watermelon density by about 8000 plants/acre from the approximate
4000 plants/acre that most commercial growers currently use (J. Faison, personal communication). Lu et al. (2003) indicated that an increase in watermelon production management intensity (especially for triploid types) will often increase profitability as the higher net returns produced can compensate for the higher production costs. However, high plant densities may demand additional fertilizer applications, and extra pesticide applications may also be warranted due to possible increases in disease and insect incidence. Although the monetary inputs required to produce mini-triploid watermelons grown at high plant densities would be higher compared with lower plant densities, the slight risk incurred would more than compensate for the potential to improve marketable yields and provide greater percentages of fruit in the 3 - to 8-lb class.

\section{Literature cited}

Duthie, J.A., B.W. Roberts, J.V. Edelson, and J.W. Schrefler. 1999b. Plant densitydependent variation in density, frequency, and size of watermelon fruits. Crop Sci. 39:412-417.

Duthie, J.A., J.W. Schrefler, B.W. Roberts, and J.V. Edelson. 1999a. Plant densitydependent variation in marketable yield, fruit biomass, and marketable fraction in watermelon. Crop Sci. 39:406412 .

Egel, D., F. Lam, R. Foster, E. Maynard, R. Weinzierl, M. Babadoost, H. Taber, B. Hutchison, and L. Jett. 2006. Midwest vegetable production guide for commercial growers 2006. Univ. Illinois Ext. Bul. C1373-06.

Fiacchino, D.C. and S.A. Walters. 2003. Influence of diploid pollinizer frequencies on triploid watermelon quality and yields. HortTechnology 13:58-61.

Herman, R.J. 1979. Soil survey of Jackson County, Ill. Illinois Agr. Expt. Sta. Soil Rpt. 106.

Lu, W., J.A. Duthie, B.W. Roberts, M.J. Taylor, and J.V. Edelson. 2003. Partial budget analysis of effects of crop management intensity on profitability of three watermelon cultivars. J. Veg. Crop Production 9:49-71.

Maynard, D.N. and P.M. Perkins-Veazie. 2004. Triploid miniwatermelon cultigen evaluation Spring 2004. 17 Nov. 2008. < http:/ / watermelons.ifas.ufl.edu/miniSP04/triploid_ minimelon_cultigen.htm>.

Meister, H.S. 2004. Sample cost to establish and produce watermelon. Univ. Calif. Coop. Ext. Publ. WT-IM-04.

Motsenbocker, C.E. and R.A. Arancibia. 2002. In-row spacing influences triploid watermelon yield and crop value. HortTechnology 12:437-440.

NeSmith, D.S. 1993. Plant spacing influences watermelon yield and yield components. HortScience 28:885-887.

Sanders, D.C., J.D. Cure, and J.R. Schultheis. 1999. Yield response of watermelon to planting density, planting pattern, and polyethylene mulch. HortScience 34:1221-1223.

Sanders, D.C., W.P. Cook, and D. Granberry. 1995. Plasticulture for commercial vegetables, North Carolina Coop. Ext. Serv. Bul. AG489.

Schultheis, J.R., W.B. Thompson, W.R. Jester, and R.L. Hassell. 2007. Mini triploid watermelon cultigen evaluations for yield and quality, and marketing in the United States. Acta Hort. 731:171-181.

Smith, S.A. and T.G. Taylor. 2007. Production costs for selected Florida vegetables, p. 115-118. In: S.M. Olson and E. Simonne (eds.). Vegetable production guide for Florida. Univ. Florida Coop. Ext. Serv. Publ. FRE 145.

Strang, J., A. Satanek, K. Bale, J. Snyder, C. Hart, and C. Smigell. 2004. Triploid mini watermelon variety trial, p. 208-211. In: E.T. Maynard and C.C. Gunter (eds.). Midwest vegetable variety trial report for 2004. Purdue Univ. Bul. 17538.

Strang, J., A. Satanek, K. Bale, J. Snyder, C. Hart, and C. Smigell. 2005. Triploid mini watermelon spacing trial, 2005, p. 161-163. In: E.T. Maynard and C.C. Gunter (eds.). Midwest vegetable variety trial report for 2005. Purdue Univ. Bul. 17810.

Thompson, B. and J. Schultheis. 2008. Yield response to planting density varies among mini watermelon cultivars. HortScience 43(4):1084. (Abstr.). 